three days. After thirty hours of flying, Mr. Mollison landed successfully at Pennfield Ridge, New Brunswick; it appears that he had sufficient fuel to go on, but was obliged by fatigue to come down. He was flying a Puss Moth aeroplane with a 120 h.p. Gipsy engine, such as is supplied to private owners, with the exception that the passenger seat has been replaced by petrol tanks. It is stated in the Daily Mirror that the direct costs of the flight were only $£ 106 s$. $3 d$. for petrol and 15s. for oil. Mr. Mollison is the first to cross the Atlantic from east to west in a solo machine, which, incidentally, is the smallest to accomplish the crossing. The flight is a noteworthy tribute to the endurance of both man and machine.

\section{Late Bronze Age Settlement in Shetland}

A LATE bronze age settlement of considerable extent has been brought to light by excavation under the Office of Works at Sumburgh, at the southern end of the Shetlands. Previous excavation had revealed an iron age site, dating from about the beginning of the Christian era. During the present season, according to a correspondent in the Times of Aug. 19, six weeks' excavation has completely cleared one dwelling, partially cleared two more, and indicated the existence of others. The completely excavated dwelling shows evidence of four occupations, of which the third, as is shown by broken clay moulds, was much taken up with bronze-casting. It is $31 \mathrm{ft}$. in length, has an original and a secondary entrance, and three chambers with four lesser chambers opening out of them. The walls are three feet high and are built of selected pebbles from the shore, neatly fitted and without filling, except in the lower courses, where clay has been used to keep out the damp. Slate was much in use for tools. Both slate and stone implements show types not in use on the mainland. Of the partially excavated houses, the walls of one pass under those of the excavated house, and are therefore older. Slate was in use here. Though pottery is scarce, the ornament on one sherd gives a bronze age date. The second partially excavated dwelling is older again; but a sword and pottery of the type of Heathery Burn Cave, Co. Durham, still point to the late bronze age. Although the full extent of the settlement is not yet revealed, the existence of several other dwellings has been noted. When excavation is complete, the settlement will probably prove the most elaborate in plan of any known bronze age dwelling-place in Britain.

\section{Roman Villa at Southwick}

IT is announced that the Roman villa at Southwick has been given to the Sussex Archæological Trust with the object of ensuring its preservation. The villa is one of a chain of Romano-British buildings, probably farms, on a four-mile belt of fertile land south of the Downs, the others being at Kingston, Portslade, West Blatchington, and Brighton. The site has been excavated by Mr. S. E. Winbolt and others, with the aid of the Sussex Archæological Society. It was found to consist of a triangular block of buildings enclosing a courtyard approximately $200 \mathrm{ft}$. by $130 \mathrm{ft}$. The chief rooms are on the north side, where they are protected from the wind by the Downs; while verandahs on the sunny side face the sea. The buildings are solidly constructed, with walls $2 \mathrm{ft}$. and $3 \mathrm{ft}$. thick, and consist of rubble cores faced with flint. The site is at present unfenced; but as soon as funds have been raised, the northern portion containing the main buildings, which unfortunately is separated from the southern by the new road, will be fenced and reconditioned to enable the public to be admitted at a small fee. The Trust, to which the site has been handed over, was formed in connexion with the Sussex Archæological Society for the preservation of the ancient monuments of Sussex, and already holds in trust Lewes Castle, Wilmington Priory, the Long Man of Wilmington, the Marlipins at Shoreham, and Oldland Mill at Keymer.

\section{Earliest known Pueblo Dating}

DR. Frank H. RoBerts, Jr., who is in charge of an expedition of the Bureau of American Ethnology excavating Pueblo settlements on a site near Allentown, Arizona, is reported by Science Service, of Washington, D.C., to have obtained from one of the houses he has excavated beams which, according to the tree-ring chronology, were cut in the year A.D. 797. This is the oldest date for which evidence has been found in Pueblo ruins in the south-western United States. The dwelling was a pit-house, built largely underground, with an entrance through the roof. It had been destroyed by fire, the inhabitants leaving most of their belongings behind them, including much pottery. The oldest dates previously established by means of the tree-ring calendar elaborated by Prof. Douglass were A.D. 919 from a beam at Pueblo Bonito, and A.D. 861 from a piece of timber at Una Vida. Both these sites are situated in New Mexico.

\section{Electric Tramcar Systems}

AвоUт the beginning of the present century many local authorities undertook the installation of electric tramway systems in cities and towns, and many workers reaped the benefit of this system of transport. The coming of the petrol bus has led many to think that in a few years' time tramways will disappear. Their immobility often causes tramway congestion, and intending passengers have to cross a stream of traffic in order to board them, unless this stream be temporarily arrested. When one sees the great part played by tramcars in cities like London, Glasgow, and Manchester, and in many cities abroad, where tramcars with two or three trailers attached are continually going through crowded streets, it is obvious that it will be many years before they are obsolete. The large number of tramcars in Austria which were installed more than twenty years ago on the supposition that vehicles would always drive on the lefthand side of the road has led to difficulties in certain districts where one must now drive on the right-hand side. The cost of obtaining uniformity by altering the tramway lines in Austria is prohibitive at the present time. Just as in the case of weights and measures, what has been done in the past makes it 